
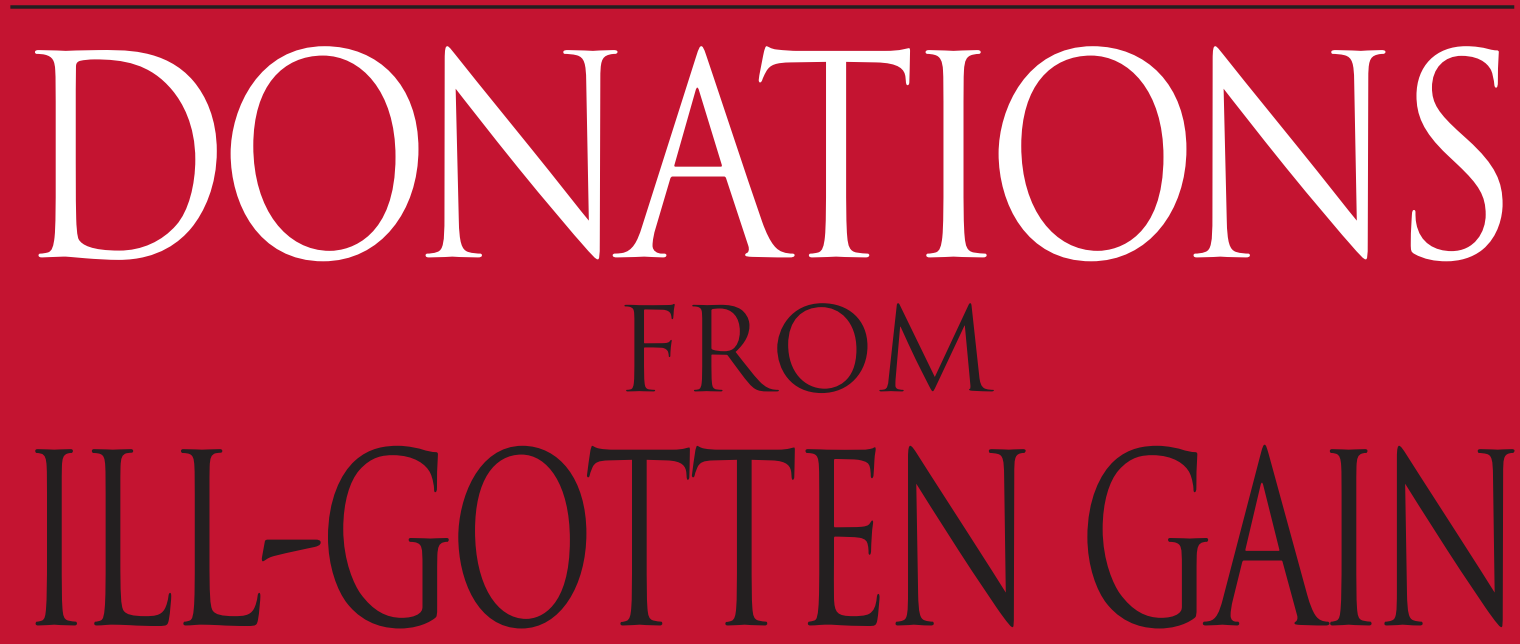

A J E W I S H

ELLIOT N. DORFF 


\title{
DONATIONS FROM ILL-GOTTEN GAIN
}

\section{A JEWISH LEGAL PERSPECTIVE}

\author{
Elliot N. Dorff
}


(C) 2008 by Elliot N. Dorff

Excerpts of more than 100 words from this publication may not be reproduced without permission. Editorial questions and permission inquiries may be addressed to:

Publications Department

The Center on Philanthropy at Indiana University

550 W. North St., Suite 301

Indianapolis, IN 46202-3272

Telephone: 317-274-4200

Web site: www.philanthropy.iupui.edu

Design and layout by Beyond Words, Inc. 


\section{FORWARD}

The Center on Philanthropy at Indiana University is proud to be home of the Lake Institute on Faith \& Giving. The Lake Institute provides a unique public forum for exploring the connections between individual philanthropy and faith while fostering a greater understanding of the ways in which faith both inspires and informs giving. In addition, scholars contribute to research on the role religion plays in philanthropy and other philanthropic issues relevant to churches, communities and nonprofit organizations.

Among the Institute's exemplary programs is the annual Thomas H. Lake Lecture, named for Thomas Lake, a man of deep religious faith and philanthropic generosity. In his personal and business life, Mr. Lake was dedicated to bringing about community change for the common and social good via faith and charitable giving. Through this lecture in his name, we engage the community in thoughtful discussion on philanthropy and religion. The Lake Institute on Faith \& Giving was established as the result of the generous legacy of Tom and Marjorie Lake and their daughter, Karen, to Indiana University.

Rabbi Elliot Dorff, Ph.D., who gave the Institute's sixth annual lecture, is a national expert on issues of Jewish theology, law and ethics, especially in the medical sciences, having served on the Ethics Committee of Hillary Rodham Clinton's Health Care Task Force in 1993. Currently, Rabbi Dorff is Rector and Distinguished Professor of Philosophy at American Jewish University.

In his lecture, Rabbi Dorff examines the ethical conundrum of nonprofit institutions receiving gifts from ill-gotten gains and addresses it from the perspective a Jewish legal case study. Institutions generally do not seek out funding from sources of

ill-repute, but what happens when a gift received in good faith is later discovered to have been tainted? This lecture provides nonprofit professionals, as well as armchair attorneys and those interested in religion's role in today's society, a scholarly and also practical way to evaluate contributions and donors of ill-gotten gain.

Patrick Rooney

Executive Director

The Center on Philanthropy

September 2009 


\section{Donations from Ill-Gotten Gain}

The Jewish tradition uses many resources to resolve moral dilemmas, to teach moral norms, and to motivate moral behavior. These include stories, proverbs, history, theology, modeling, study, and law. Although all of these aspects of Judaism can be and are used to determine what morality demands, to teach morality, and to motivate moral behavior, law is the principal way in which the Jewish tradition seeks to resolve moral conundrums. Like every other mechanism used for these moral purposes, law has some significant disadvantages as well as some clear advantages in accomplishing these ends. ${ }^{2}$

Like Anglo-American law and unlike European Continental law, Jewish law works primarily through cases, in which judges respond to a specific set of circumstances and then their ruling can be used to inform later courts as to how to rule in similar cases. (Continental law instead works deductively from codes.) On hard cases, rabbis will describe the situation to another rabbi with known expertise in the relevant area of the law, and that rabbi will respond with a judicial ruling. This literature is called, in Hebrew, she'ailot u'teshuvot ("questions and answers"), or, in English, the responsa literature (singular, responsum).

So to illustrate how the Jewish tradition deals with moral questions, I will present here an actual case that I was asked to rule on some six months ago. An earlier draft has been discussed once by the Conservative Movement's Committee

I would like to thank the members of the Committee on Jewish Law and Standards, the people who heard and commented on an earlier draft of this at the Center on Philanthropy at Indiana University in Indianapolis, especially Professor Robert Katz, and Rabbi Elie Spitz's adult study group - most especially Dr. Neil Spingarn, who sent me a detailed memo of five important comments after my session with that group - for their insightful questions, comments, and suggestions on earlier drafts of this responsum.

${ }^{2}$ I discuss how Judaism uses all of these resources to address moral questions as well as the advantages and disadvantages of using law for this purpose in my book, Love Your Neighbor and Yourself: A Jewish Approach to Modern Personal Ethics (Philadelphia: Jewish Publication Society, 2003), Appendix, pp. 311-344. 
on Jewish Law and Standards, and this draft will be discussed and probably voted on at the next meeting of the Committee in June 2009. Hopefully my ruling will be interesting and informative not only on the specific issue discussed, but also as an illustration of how one religious tradition grapples with hard moral dilemmas.

\section{The Situation:}

Mr. and Mrs. Jones (not their real family name) send their children to Camp Ramah and have become very friendly with the Ramah community, to the extent that Mrs. Jones is on the Ramah Board. Several years ago they donated money to Ramah. It was used primarily to build a facility at camp that bears their family name, but there is still some money left over for Ramah to use for other purposes. Mr. Jones was just indicted by a grand jury for money laundering and stock fraud, and the cover story in the local Jewish newspaper described the indictment in great detail. Their synagogue's rabbi gave a sermon on the Shabbat following the indictment denouncing Mr. Jones and announcing that the facility that they had donated to the synagogue in the Jones family name would no longer bear their name.

Because this case arose at a Ramah camp, I will use Ramah as my example throughout this responsum. Its reasoning and conclusions, however, apply equally to any Jewish communal institution - synagogues, schools, federations, social service agencies, and national and international organizations like the United Synagogue of Conservative Judaism and the Rabbinical Assembly.

\section{Questions (She'ailot):}

1) May or should Camp Ramah treat Mr. Jones as if he were already convicted of the crime of which he is accused after he is indicted but before he is convicted?

2) If Mr. Jones is convicted of the crime of which he is accused, may or should Camp Ramah remove the Jones family name from the facility that they donated? What if the facility had been named for Mr. Jones alone?

3) Must Camp Ramah use money it has raised from other sources to return to the Jones family the amount of money they donated if it has already been used to build the building in their name?

4) Must Camp Ramah return the money the Jones family donated that has not yet been used?

5) May Camp Ramah accept any further donations from Mr. Jones?

6) May Camp Ramah accept any further donations from the Jones family? 


\section{Response (teshuvah):}

\section{Defining “Ill-Gotten Gain”}

This case, in one important way, is easier to address as a matter of law than it might be. Specifically, in this case Mr. Jones was indicted and later convicted of felonies that affected the money he donated to Ramah. Sometimes, though, nonprofits are faced with much stickier problems, in which the donor obtained the money donated in ways that were legal but less than honorable. What happens then?

Jewish Family Service of Los Angeles (JFS) was faced with this when the Philip Morris Company offered to donate money to one of its programs on condition that Philip Morris be allowed to advertise that it supported JFS. The JFS Board ultimately accepted the money on the grounds that Philip Morris had become a conglomerate that at the time included Kraft Cheese and a number of other products that are not addictive, and so the $\$ 10,000$ it was donating might well have come from money it earned on products other than cigarettes. The JFS Board stipulated, however, that the company may not advertise the donation because the company's name was still associated in the public mind primarily with cigarettes. Cigarettes are, after all, legal, but JFS runs drug and alcohol abuse programs, and cigarettes are equally addictive. The company's product thus undermines one of the goals of the JFS mission.

In the discussion, however, one of the Board members, a major contributor to the agency, noted that he earns his money by importing clothes from Asia. He does his best to make sure that employees there work in reasonable conditions, but he has limited control over that, and he knows that Americans would call the places where the workers manufacture the clothing "sweatshops." "So should JFS refuse my money?" he asked. That is, morally tainted money is not necessarily illegally earned. ${ }^{3}$

Because the case that motivated the writing of this responsum concerns money that was legally as well as morally tainted, my treatment of it in what

\footnotetext{
${ }^{3}$ When I presented this responsum in an earlier draft as the Lake Lecture at the Center on Philanthropy at Indiana University, Dr. Eugene Tempel suggested a number of other cases where money was legally earned but morally tainted. He pointed out, for example, that Stanford University accepted \$100 million from Exxon for a research project, but then one donor cancelled his $\$ 2.5$ million gift because the Exxon gift, in his view, undermined his environmental concerns. Master $\mathrm{P}$, a gangster rapper making \$50 million a year, contributed substantially to the New Orleans Catholic school in which he had been a student (St. Monica Elementary School). The lyrics of Master P's rap music degrade others, but if the archdiocese refused the gift, the school, which now serves many disadvantaged children from broken homes, would have to close. The archdiocese asked two moral philosophers what they should do. They told the archdiocese that it could accept the money because it was coming from his clothing and professional sports investments, not from his music, and, in any case, Master P was only his stage persona and not the real person who was donating the money. As discussed below, this sounds like many of the distinctions that Jewish law makes.
} 
follows will not deal in detail with moral concerns that may lead a nonprofit to refuse a potential donor's gift. I will say, though, that once one enters the domain of legally ill-gotten gain, it becomes very difficult, if not impossible, to draw any bright lines that would distinguish gifts from sources that are morally acceptable from those that are not. That is true as well for violations of Jewish ritual law; indeed, no Jewish organization I know of, including ultra-Orthodox ones, refuse gifts from people who violate, for example, the dietary or Sabbath laws. Furthermore, as we will see below, nonprofits may and should presume that the money being offered to them is legitimately and morally earned until and unless the donor is a "well-known thief" (a ganav mefursam), at which point the burden of proof shifts and the nonprofit must investigate the source of the money proffered. Normally, though, nonprofits need not investigate the sources of potential gifts. On the other hand, nonprofits depend for their support on the trust of others, and if a gift undermines an agency's integrity, it may be unwise to accept it. The decision of a nonprofit to refuse a gift on moral grounds or because it conflicts with its best interests, however, must be an ad hoc one, based on the mission of the nonprofit and the specific circumstances of the gift.

\section{Between Indictment and Conviction}

At the moment, Mr. Jones is indicted but not convicted. Jewish law is even more insistent than American law that a person is innocent until proven guilty: in American law, one may confess to both civil and criminal liability, but in Jewish law one may confess to civil liability (hoda'at ba'al din k'me'ah edim dami) but not to culpability for a crime, for "one may not make oneself a wicked person" (ain adam masim atzmo rasha). ${ }^{5}$ In both systems of law, courts must presume innocence. ${ }^{6}$ Thus, during the time between the indictment and the court verdict, rabbis need to inform anyone who asks about this case that the strong presumption

\footnotetext{
${ }^{4}$ B. Gittin 40a, 64b; B. Kiddushin 65b; B. Bava Metzia 3b. In this and all other footnotes, M. = Mishnah (edited by Rabbi Yehudah, President of the Sanhedrin, c. 200 C.E.), B. = Babylonian Talmud (edited by Ravina and Rav Ashi, c. 500 C.E.), M.T. = Maimonides' Mishneh Torah (completed c. 1177 C.E.), S.A. = Joseph Caro's Shulhan Arukh (completed c. 1565 C.E., and usually published with glosses by Rabbi Moses Isserles to indicate where Northern European [Ashkenazic] practices differed from those of Mediterranean [Sephardic] Jewry, as reflect in Caro's work.

${ }^{5}$ B. Yevamot 25b; B. Ketubbot 18b; B. Sanhedrin 9b, 25a. For an extensive treatment of this topic, see Aaron Kirschenbaum, Self-Incrimination in Jewish Law (New York: Burning Bush Press, 1970).

${ }^{6}$ Yehudah ben Tabbai says that judges should see the litigants standing before them as all guilty, and only after the verdict should judges see the litigants as innocent, "for they have accepted the judgment" (M. Avot 1:8), but that is probably advice to judges to be skeptical of what litigants say rather than an assertion of their legal guilt. After all, Jewish law establishes much stricter rules of evidence to establish guilt than American law does, requiring two witnesses who are unrelated to the accused, to the litigants, or to each other, banning hearsay evidence, etc.
} 
of innocence in Jewish law requires everyone to think and act accordingly; failure to do so is a violation of the prohibition to slander others (motzi shem ra). ${ }^{7}$

\section{After Conviction: Removing the Name of the Jones Family or Mr. Jones from the Jones Building}

Suppose, however, that Mr. Jones is convicted of the crimes of which he is accused, either through a confession on his part (perhaps as part of a plea agreement) or through a formal trial. May - or should - Ramah remove the family name from the building the Jones Family donated the money to construct?

First, although the ladder of levels of tzedakah (charity), articulated first by Maimonides (Rabbi Moses ben Maimon, 1135-1204, Spain and Egypt) and repeated in the Shulhan Arukh by Rabbi Joseph Caro (1488-1575, Spain and Israel), much prefers that gifts be given anonymously, that applies to donations to poor people who might well be embarrassed to be in need of such gifts. ${ }^{8}$ It does not apply to institutions, where Jewish law specifically permits named facilities "so that he [the donor] will be remembered... and it is fitting to do this." 9

Should, though, a name be removed if the donor is convicted of a felony? Even though a pervasive principle in the Talmud is that we should not reward a sinner (shelo yeheh hoteh niskar), ${ }^{10}$ even more important, in my view, is the equally pervasive Talmudic principle that we must uphold people's honor ${ }^{11}$ and, conversely, avoid embarrassing them. This especially applies to innocent people and to public embarrassment. Indeed, the Talmud compares one who embarrasses people in public to a murderer, ${ }^{12}$ and it denies a place in the World to Come to someone who embarrasses another in public. ${ }^{13}$

Because the Jones children are part of the Ramah family and are enrolled for the upcoming summer, avoiding embarrassment for them must be a prime concern in deciding whether the family name should be removed from the facility by which it has been known for several summers. The children, after all, are

\footnotetext{
${ }^{7}$ M.T. Laws of Ethics (De'ot) 7:2-3.

${ }^{8}$ M.T. Laws of Gifts to the Poor 10:7-14; S.A. Yoreh De'ah 249:6-13.

${ }^{9}$ S.A. Yoreh De'ah 249:13, gloss, based on responsum \#582 of the Rashba. I would like to thank Rabbi Daniel Nevins for pointing out this aspect of the situation and this source.

${ }^{10}$ B. Ketubbot 11a, 36b, 39b; B. Sotah 15a; B. Gittin 55b; B. Bava Kamma 39a; B. Menahot 6a, 6b; B. Niddah $4 \mathrm{~b}$. See also the following passages, in which the prospect of a sinner being rewarded serves as an objection to a possible ruling: B. Yevamot 92b; B. Bava Kamma 38a; B. Avodah Zarah 2b.

${ }^{11}$ B. Berakhot 19b; B. Shabbat 81b, 94b; B. Eruvin 41b; B. Megillah 3b; B. Bava Kamma 79b; B. Menahot

37b, 38a. For a detailed discussion of this principle, see the responsum by Rabbis Daniel Nevins, Avram

Reisner, and me, "Homosexuality, Human Dignity, and Halakhah," Section IV (that section was primarily

written by Rabbi Nevins) at www.rabbinicalassembly.org under the link "Contemporary Halakhah."

${ }_{12}$ B. Bava Kamma 58b.

${ }^{13}$ B. Sanhedrin 107a.
} 
innocent of any crime, and we should not harm them any more than they have already been hurt by what their father has been convicted of doing.

Indeed, the Jewish community should not embarrass Mr. Jones himself any more than his conviction already has. Thus in his sermon's public denunciation of the Jones family, their synagogue's rabbi clearly transgressed Jewish law, for he thereby subjected Mr. Jones and his family to shame in front of the entire congregation. Mr. Jones at that time was only indicted, not convicted, and that makes the rabbi's actions even worse; but even if the rabbi spoke after Mr. Jones had been convicted, his family is innocent and should certainly not have been subjected to public humiliation. Furthermore, it is not the role of the rabbi to shame Mr. Jones beyond what his sentence already involves. In fact, Jewish law requires that one who embarrasses another pay damages for the shame (boshet) involved, ${ }^{14}$ and so Mr. Jones' family, and perhaps even Mr. Jones himself, may actually have a legal remedy against the rabbi who acted as he did. For the same reasons, even if Mr. Jones is convicted, Ramah should not on its own initiative remove the family name for fear of causing further embarrassment to both him and his family. Indeed, the Mishnah specifically allows a community to honor someone with a moral cloud over his head:

Similarly, if an [accidental] killer was exiled to a city of refuge and the people of the city wanted to honor him, he should say to them, "I am a killer." If they say to him, "Even so [we want to honor you,]" he may accept [the honor] from them, as the Torah says (Deuteronomy 19:4), "This is the word of the killer" [where "word" is in the singular, suggesting that the killer need only tell them once and need not repeat his announcement of his tainted moral status]. ${ }^{15}$

Furthermore, Ramah needs to check the agreement that it made with the Jones family before even considering whether to remove their name from the facility built with their funds. If they specifically donated money on condition that it be used for this facility and that it be named for them, and if Ramah accepted these conditions, Ramah has no right to remove it, either in civil law or in Jewish law. ${ }^{16}$ Ramah may be legally entitled to return all of the Jones family money and then remove the name, but without stipulation of reasons to remove the family name in Ramah's contract with the Jones family, even this is questionable.

The only condition under which the Jones family name may and should be removed from the facility they donated the money to construct is if the family

${ }_{14}$ M. Bava Kamma 8:1, 6; B. Bava Kamma 83b, 86b.

${ }^{15}$ M. Shevi'it 10:8; M. Makkot 2:8. I would like to thank Rabbi Daniel Nevins for pointing this Mishnah out to me. The interpretation in square brackets is based on the Tosefta (T. Makkot 2:2, toward the end).

${ }^{16}$ S.A. Yoreh De'ah 259:2 gloss; see also 256:4 gloss. 
itself requests this. The Ramah director and/or someone else he or she deems appropriate should offer supportive counseling to Mr. Jones and his family in this time of need; after all, this is a family that has been actively involved in supporting the camp. As part of this counseling the Ramah representative should raise the issue of the named facility, explaining to the Joneses that the primary concern in deciding whether to have their name removed or not is to avoid any further shame to themselves and their children.

In considering the removal of the family name from the Ramah building, Mr. Jones and his family should be counseled to consider a number of factors. They may want to remove Mr. Jones and his criminal activities from further public notice. They may also want to prevent any further embarrassment for his children attending camp in future summers, for the name on the building might remind them and their friends of the illegal way their father financed his donation to build it. For that matter, in light of the fact that adults come up to camp for visitors' day and weekends, they may want to save not only their children, but themselves, too, from further embarrassment. ${ }^{17}$ Because they clearly feel connected to Ramah, they may, in addition, want to protect Ramah from any embarrassment. Ramah authorities may discuss these ramifications with Mr. Jones and his family to explore the best way to maintain the family's dignity. If Mr. Jones decides that Ramah should quietly remove the name to prevent further embarrassment, Ramah may do so.

No matter what happens to the Jones name on the facility, the community has the duty to remember that the Jones family, and even Mr. Jones himself, are not fully identified by Mr. Jones' misdeed(s) and should not be so in the public mind. After all, in this particular case and in many like it, Mr. Jones and his family have also contributed substantially to charitable institutions, not only in money but in time and effort. Thus even if we would condemn the fraud for which Mr. Jones has been convicted, and even though we would support whatever the courts decide is a fair punishment so that justice is done, we need to be supportive of his family and, indeed, of Mr. Jones himself as he and they go through this painful period in their lives. Wrongdoers should be punished, but that is the function of the state or federal government, not of Ramah.

To this point, I have responded to the actual case. For broader application, however, I must note that how one rules on this question depends in part on the

17 To his credit, in the 1986 case, Mr. Ivan Boesky asked Chancellor Gerson Cohen to remove the Boesky family name from the new library building that his money was helping to construct the morning before he was indicted for securities fraud so as not to embarrass the Jewish Theological Seminary. 
other grounds that would lead the nonprofit organization to remove a name. For example, would it remove the name of donors who did not pay their pledge for this building? If so, the level of malfeasance that triggers this action in the community that supports this organization is apparently lower than actual crimes, and so removing the name may not be as shameful as it would be in other contexts. That is, community standards play a role in this decision, especially if they are built into contract with major donors.

The decision about removing the name also depends critically on the level of the crime. The Torah, after all, speaks of the wages of male and female prostitutes, and the Talmud speaks of taking money from a thief. What if the crime were either less or more serious than the fraud involved in this case?

Clearly, if Mr. Jones had gotten a parking ticket or had violated the law in some other minor way, his name should definitely not be removed from the camp's facility, for his violation of the law does not rise to the level of seriousness that should even raise this question. Further, the ease with which Mr. Jones can redeem himself from the penalty for such a violation also speaks to the inappropriateness of even considering shaming him in this way.

On the other hand, if Mr. Jones's crimes were even more serious than they are alleged to be in this specific case - if, for example, he had not only committed fraud but also some violent crime, or if his crime involved, as is alleged against Agriprocessors, multiple criminal acts that go beyond monetary violations (blackmail, immigration and labor violations, etc.), or if, as in the case of Bernard Madoff, Mr. Jones were accused only of monetary crimes but to a much more extensive degree - then Ramah should think more seriously about taking whatever legal steps are necessary to remove his name from the nonprofit's facility. Here it seems that the balance tips in the other direction, where the modeling that is involved in publicly honoring someone, and the values of the community represented by that modeling, should take precedence over the extra shaming that may be involved in removing Mr. Jones' name from the facility. Moreover, if Mr. Jones committed violent or otherwise egregious crimes, the shame he might endure by seeing his name removed from the facility pales by comparison to the shame he has brought upon himself through the crimes themselves.

Where, though, is the line for triggering this response? If it is felonies as against misdemeanors, then white-collar felonies, such as the ones Mr. Jones committed, should also lead Ramah to seek to remove his name. If only violent crimes count, exactly which crimes are we categorizing that way? This is a very 
slippery slope, and if all crimes disqualified donations, most, if not all, charities would cease to exist. Exactly how pure must donated money be, and how would a charity know this?

In the end, then, Ramah and all other charities should either attempt to specify in their contracts with major donors the conditions under which they are accepting money and offering honors for it or resign themselves, when faced with this kind of situation, to being able only to try to convince the donor and/or the family to agree to remove their name from the facility they donate. Because of the difficulty of specifying such conditions in legal contracts - apart from failing to pay one's full pledge - discussion with the donor(s) is the best way to proceed when faced with this question.

\section{After Conviction: Returning Donated Money that Had Already Been Used}

Again supposing that Mr. Jones is convicted of the felony of which he is accused, must Ramah return the money the Jones family donated if the camp has already used it to build the intended facility?

Some introductory remarks will help readers understand the rest of this responsum. First, in English Common Law and, through it, in American law, "theft" is the dishonest appropriation of property with the intention permanently to deprive the owner of it; "robbery" is theft with assault; and "burglary" is theft with trespass. ${ }^{18}$ Jewish law similarly distinguishes among forms of theft. Specifically, both the Torah and later Rabbinic literature distinguish between robbery (gezailah) and burglary (genaivah). As in English Common Law and American law, robbery (gezailah) is taking something owned by someone else by force; burglary (genaivah) is acquiring someone else's property through trespass, either when the owners are not home or at night. ${ }^{19}$ According to Jewish law, a robber need only return what he robbed, although in cases of embezzlement, false oath, or breach of trust, he or she must also pay a $20 \%$ fine plus bring a guilt offering to the Temple. The penalty for burglary is a $100 \%$ fine -that is, the thief must pay the owner double what he or she stole - but he or she can escape that fine by admitting the burglary, and thus pay the owner only what he or she stole. ${ }^{20}$

${ }^{18}$ I would like to thank Deborah Silver, a British barrister and a rabbinical student at the Ziegler School of Rabbinic Studies, for making these distinctions clear to me.

${ }^{19}$ M.T. Laws of Burglary (Genaivah) 1:3; M.T. Laws of Robbery and Loss (Gezailah v'Avaidah)1:3.

${ }^{20}$ Only the principle for robbery: M.T. Laws of Robbery and Loss 1:5. An extra 20\% fine and a guilt offering if he denied that he robbed: Leviticus 5:24-25. A thief must pay double: Exodus 22:2-8; however if he admitted the theft, he need only pay back the principle: B. Bava Kamma 63b, 64b, 106a; M.T. Laws of Burglary 1:4-5. 
This immediately raises a question: why is theft, even with assault, punished less than theft with trespass? One might justify the harsher penalty for burglary on the basis of the fact that people are more vulnerable at night, and therefore the law had to penalize criminals who steal at night more severely to deter such crimes. Alternatively, the harsher penalty might be because the secrecy of the theft made it harder for authorities to identify and catch the thief. The Talmud, however, instead explains the difference theologically: the robber has no respect for either human or divine law, and thus puts God and human beings on an even plane; the burglar, on the other hand, apparently fears human legal authorities and therefore steals at night to hide from them, but in stealing he violates God's law, and so he respects God less than human beings and therefore must be more severely punished for both his legal and theological violations. ${ }^{21}$ Like other biblical fines and penalties, already in Talmudic times these fines for burglary fell into desuetude because the rabbis of that time did not think that they had the jurisdiction to adjudicate fines after the demise of the Sanhedrin in 361 C.E. brought an end to the chain of judicial authorization, ${ }^{22}$ and so in practice both robbers and burglars need to return only what they stole.

Although the Torah requires that a thief return the exact object that he took - "he restores that which he robbed" (Leviticus 5:23) - the Rabbis enacted a change to encourage thieves to repent (takkanat ha-shavim), such that thieves who changed a stolen object permanently need only repay the monetary value of what they took rather than the object itself, and they pay only what it was worth at the time of the theft. ${ }^{23}$ The Rabbis did this, no doubt, because they wanted to encourage the thief both to change his ways and to compensate the victim, for they saw the law as functioning not only to punish wrongdoers but to move them to become law-abiding and moral people. This is one example of a broader feature of Jewish law, which sees the purpose of criminal justice not so much as retribution but as compensation of the victim, repair of the rift in the communal fabric, and rehabilitation of the criminal. ${ }^{24}$

In addition, the Rabbis instituted takkanat ha-shuk, the enactment of the market, according to which a person who acquired something not knowing that it

\footnotetext{
${ }^{21}$ Mekhilta, "Mishpatim," Chapter 15; B. Bava Kamma 79b.

${ }^{22}$ B. Bava Kamma 84a-b; see also B. Bava Kamma 27b and B. Sanhedrin 13b-14a.

${ }^{23}$ B. Gittin 55a; B. Bava Kamma 66a-b, 94a-b; M.T. Laws of Robbery and Loss 2:1-2

${ }^{24}$ For more on this, see Elliot N. Dorff, Love Your Neighbor and Yourself: A Jewish Approach to Modern Personal Ethics (Philadelphia: Jewish Publication Society, 2003), pp. 207-230 and pp. 337-344; and Elliot N. Dorff, For the Love of God and People: A Theory of Jewish Law (Philadelphia: Jewish Publication Society, 2007), pp. 212-222.
} 
was stolen need not give the original owner either the property or its value unless the seller was a known thief. ${ }^{25}$ They instituted this rule "because otherwise no person would purchase anything, for fear that it had been stolen.”26

Now, then, let us address our question. The Prophets warn us repeatedly against complicity in illegal actions and their financial earnings. Amos, chronologically the very first of the literary prophets of the Bible, already sets the tone:

Listen to this, you who devour the needy, annihilating the poor of the land, saying, "If only the new moon were over so that we could sell grain, the sabbath, so that we could offer wheat for sale, using an ephah [a dry measure] that is too small and a shekel that is too big, tilting a dishonest scale and selling grain refuse as grain! We will buy the poor for silver, the needy for a pair of sandals." The Lord swears by the Pride of Jacob: "I will never forget any of their doings." Shall not the earth shake for this and all that dwell on it mourn? ... ${ }^{27}$

Furthermore, Deuteronomy 23:19 specifically forbids us from accepting for the Temple any donation whose source is ill-gotten - in its specific case, the wages of a harlot.

You shall not bring the fee of a whore or the pay of a dog [= a male prostitute] into the house of the Lord your God in fulfillment of any vow, for both are abhorrent to the Lord your God.

The Talmud and the codes then make it clear that it is forbidden - "a great sin"

- to acquire stolen property from a burglar or robber:

It is forbidden to acquire from a burglar the object that he stole, and it is a great $\sin$ [to do so], for that strengthens the hands of those who violate the law and causes him to steal other things, for if he would find no buyer, he would not steal, and on this Scripture says, "He who shares with a thief is his own enemy" (Proverbs 29:24). ${ }^{28}$

\footnotetext{
${ }_{25}^{25}$ M. Bava Kamma 10:3; B. Bava Kamma 115a (and see Rashi there, s.v. takkanat ha-shuk); M.T. Laws of Burglary 5:2-3 (cited and translated below); M.T. Laws of Robbery and Loss 5:7. The standard in American law for similar cases is whether you have reason to believe that the seller is a thief, which is a weaker standard and thus one that makes buyers more responsible for knowing whether the sale is legitimate - and therefore more responsible also to return the money or object to the rightful owner if it later turns out that the seller was indeed a thief. This may be based on the view of many modern economists that fear of an item being stolen decreases the value of every item on the market (because buyers will pay less for any item that may be stolen and that they therefore might have to be return), but this fear would not block market transactions altogether. Normally, Jews think of Jewish law as more demanding than secular law, given that Jewish law is a religious legal system with deep roots in morality, in contrast to secular law whose primary purpose is to establish rules to ensure order. (On this, see Elliot N. Dorff, For the Love of Law and People: A Philosophy of Jewish Law [Philadelphia: Jewish Publication Society, 2007], Chapter Six.) Here, though, the judgment of Jewish law is that the market requires that the thief actually be well-known (literally, "famous" as a thief) for a sale to be overturned. I want to thank Professors Robert Katz and David Orentlicher of the Indiana University School of Law, Indianapolis, for pointing this out to me.

${ }^{26}$ Shakh, S.A. Hoshen Mishpat 356, subpar. 4. Arukh Ha-Shulhah, Hoshen Mishpat 356:2 states the same reason for this enactment.

${ }^{27}$ Amos 8:4-8. For other examples of prophets admonishing the Israelites about their business ethics, see Isaiah 26:8-10; Jeremiah 9:3-8; 21:12-14; Micah 3:9-12; and, perhaps most famously, 6:8.

${ }^{28}$ M.T. Laws of Burglary 5:1; see also S.A. Hoshen Mispat 356:1.
} 
It is forbidden to acquire anything robbed from the robber, and it is forbidden to help him change it so that he may legally acquire it, for anyone who does these things or anything similar strengthens the hands of transgressors and violates [the Torah's law], "Before a blind person do not put a stumbling block" (Leviticus 19:14). ${ }^{29}$

Based on such sources, some might plausibly argue that Ramah should take the high moral road of returning the money that the Jones Family donated so that Ramah is not tainted in any way by Mr. Jones' illegal actions.

Ramah may choose to do this, even if it requires a major effort to replace the money that the Jones family donated. In making this choice, however, it must weigh several factors, including how much money it would need to raise to return the Jones family gift, the degree of difficulty of raising this amount of money, the other projects or programs that would suffer as a result of having to use this money for reimbursing the Jones family, the amount of negative publicity that would accompany the return of this money, and the degree to which other donors would themselves support such a move or object to it.

Although the Ramah Board of Directors may, upon taking all these factors into consideration, choose to return the money to the Jones family that was used to build the building that bears their name, Jewish law does not require it to do so. Ramah accepted the Jones money without knowing that it was ill-gotten gain; it therefore has the protection of takkanat ha-shuk, the enactment of the market, and need not return anything to either Mr. Jones or the people from whom he stole (assuming that they could be identified). Indeed, as Rabbi Ben Zion Bergman pointed out to me, the same logic that moved the Rabbis to institute takkanat hashuk to enable people to trust that they will not have to part with what they buy innocently in the market applies to charities just as well and perhaps even more. After all, given the complexities of today's market, with its manifold opportunities for individual malfeasance and for corporate wrongdoing, as reported all too often in the news, if Jewish law required returning ill-gotten donations when the charity had no reason to suspect that they were illegally procured, "that would put an onerous burden on every communal institution to question whether any major gift was pure as the driven snow, lest they have to return it later...Therefore, considering that it is in society's best interest to encourage charitable institutions and to facilitate their efficient operation, requiring the return of a charitable

\footnotetext{
${ }^{29}$ M.T. Laws of Robbery and Loss 5:1; see also S.A. Hoshen Mispat 369:1. All four of the citations in this note and the previous one are based on B. Bava Kamma 118b-119a.
} 
contribution of questionable provenance would be highly detrimental to the public interest." 30

Moreover, Ramah has already used the money Mr. Jones donated to finance the building bearing the Jones name. There has thus been a change in the nature of the gift from money to a building, and a shinnuy ma'aseh (a change in form that is irretrievable) confers ownership on the thief. ${ }^{31}$ Maimonides summarizes the law thus:

Anyone who robs [something] is required to return the robbed object itself, as the Torah says, "And he would restore that which he got through robbery" (Leviticus 5:23); but if it was lost or changed, he pays its worth. Whether he admitted on his own [that he robbed it] or witnesses testified against him that he robbed, he is required to pay only the principle. Even if he robbed a beam and built it into a palace, because it was not changed, according to the law of the Torah he must destroy the whole building and return the beam to its owners. The Sages, however, changed the law (tikknu) as an enactment for those who repent [takkanat ha-shavim] that he [the robber] should give [the beam's owner] its worth [in money] and not lose the building, and likewise with all similar cases. Even if he robbed a beam and made it part of his hut (sukkah) for the holiday [of Sukkot, when all such huts are to be temporary], and the owner came to claim it during the Festival, he need give him only the money it is worth, but after the Festival, because the beam was not changed and he did not build it into the hut with mortar, he must return the beam itself....

A robbed object that was not changed but remains as it was, even if the owners despaired [of getting it back] and even if the robber died and it is now in the hands of his sons, it itself must be returned to its owners. If, however, it was changed by the robber, even if the owners had not yet despaired of recovering it, he [the robber] acquired it through the change and he must pay its worth [to the owners] as of the time of the robbery.

This is the Torah's law, and it says, "And he would return that which he got through robbery" (Leviticus 5:23). From the oral tradition, however, we have learned that if it is as it was when he robbed it, then he returns it, but if it was changed by him, he must pay its worth... And this is the Sages' words because of their enactment for those who repent [takkanat ha-shavim]...

A change that returns to its original state is not [for these purposes considered] a change. How so? If he robbed pieces of wood and stuck them together with nails and made a box with them, that is not a change because he can break them [the boards of the box] apart and they become the boards that they were before.

\footnotetext{
${ }^{29}$ M.T. Laws of Robbery and Loss 5:1; see also S.A. Hoshen Mispat 369:1. All four of the citations in this note and the previous one are based on B. Bava Kamma 118b-119a.

${ }^{30}$ Rabbi Ben Zion Bergman, in an e-mail to me dated October 27, 2008.

${ }^{31}$ B. Bava Kamma 66a, 93b.
} 
If he robbed dirt and made it a brick, he has not acquired it because if he smashes the brick the dirt will return to the way it was. If he robbed a tongue of metal and made it a coin, he has not acquired it, for if he melts the coin, it will return to the tongue [of metal] that it was. And the same is true for all similar things.

But if he robbed pieces of wood and burned them or cut them or carved into them and made them vessels, or he robbed wool and dyed it or stripped it clean or bleached it, or he robbed thread and made clothing of it, or he robbed a brick and made it dirt, or stones and he polished them or coins and he melted them, that is a change by his hand, for if he were to make them other coins, they would have a different face. And the same is true for similar cases [of permanent change]. ${ }^{32}$

Notice that, as Maimonides stated, the reason that change of form confers ownership is to encourage the thief to repent for his thievery; it is consequently called takkanat ha-shavim, "the enactment for those who repent." One might imagine other reasons for this rule. For example, in John Locke's analysis of ownership, a person who mixes his or her labor with some item increases its value and so is entitled to some part of it, possibly even if the person acquired the item originally through theft. Alternatively, on utilitarian grounds, it would be socially wasteful to tear down the house to get the beam back, and that might justify permitting the thief to return the beam's value in money rather than the beam itself. Jewish law includes this provision, however, not for either of these reasons but rather specifically to encourage repentance. This illustrates the moral concerns that pervade Jewish law, especially, but not exclusively, in areas of business. ${ }^{33}$

If a permanent change confers ownership on a thief, it presumably has even greater power to transfer ownership to an innocent recipient of the stolen assets who permanently changes the form of what was stolen - in this case, Ramah, which changed Mr. Jones' money into a building. Thus Ramah owns the building, and, contrary to the thief, Ramah has no obligations to the people Mr. Jones defrauded to pay them back. Mr. Jones has the duty to restore to his victims the

\footnotetext{
${ }^{32}$ M.T. Laws of Robbery and Loss 1:5, 2:1-2, 10-12. See also S.A. Hoshen Mishpat 360:5-6. There is a Tosefta (T. Bava Kamma 10:12), recorded in an expanded form in the Talmud (B. Bava Metzia 21b-22a) that says that "A burglar (ganav) who stole from one person and gave to another, and similarly a robber (gazlan) who took from one person and gave to another, and similarly the Jordan River that took from one person and gave to another, what he took, he took, and what he gave, he gave," presumably even without a change in form, on the grounds, apparently, that owners despair of getting any stolen thing back, but the codes did not follow this position.

${ }^{33}$ I would like to thank Professor Robert Katz of the Indiana University School of Law, Indianapolis, for suggesting these alternative grounds to me. For Locke's theory, see John Locke, Two Treatises of Government (1690), Peter Laslett, ed. (New York: Cambridge University Press, 1960). For an overview of theories of property, see Stanley I. Benn, "Property," The Encyclopedia of Philosophy 6:491-494. That Jewish law is especially concerned with the morality of business is evident in the Talmud's claim that the very first question that a person is asked by God after death is "Did you engage in business honestly?" (B. Shabbat 31a).
} 
money he stole from them, as described by Maimonides above, but Ramah, as an innocent recipient of his money, does not have that duty.

In fact, in the specific case, Mr. Jones defrauded the government and therefore cannot really identify the specific individuals who are hurt by his actions. In such cases, the specific way that Jewish law provides for him to compensate his unknown victims is to contribute to a public charity like Ramah:

The form of return (repentance, teshuvah) for shepherds, charity collectors, and tax collectors is difficult because they stole from the public, and they do not know to whom to return [what they stole]. Therefore they should do with it [what they stole] public works, like wells, ditches, and caves. ${ }^{34}$

In light of this, some might rightfully object to Ramah using other money to reimburse the Jones family on the grounds that Ramah should not waste any money it collects and desperately needs for its sacred purposes on something like this, particularly when Jewish law specifically provides that Ramah has no duty to return it and may actually undermine Mr. Jones' ability to repent if it does so. That is, some might argue that what appears to be the high moral road is not that after all but rather an irresponsible use of money donated by others.

\section{After Conviction: Returning Donated Money that Had Not Yet Been Used}

Again assuming that Mr. Jones is ultimately convicted of the crimes for which he now stands indicted, what if some of the money that the Jones family contributed has not yet been used for the costs of completing or furnishing the building that bears their name or for any other Ramah project or program? Must Ramah return that money? After all, unlike the money that has already been used toward the construction of the building, this money has not undergone a change in form; it is still money. Thus the laws cited in the previous section invoking a change in form do not apply and cannot justify Ramah holding on to the money.

Of the three parties in the case - the original owners, the thief, and the buyer (or the receiver of a gift) - the thief is the one with presumably the least money and therefore the least likely to be able to pay a judgment against him. Thus in the laws described below, the party that has to claim against the thief is at a real disadvantage, for the thief may not be able to pay what he owes.

Mr. Jones was not a "known thief” (ganav me'fursam) before the recent accusations. If he were, the enactment of the market would not apply, and thus a change of possession would not effect a transfer of ownership. Thus Ramah would

\footnotetext{
${ }^{34}$ B. Bava Kamma 94b; S.A. Hoshen Mishpat 366:2.
} 
have to give the money back to its original owners (in this case, the government) and seek to force $\mathrm{Mr}$ Jones to make good on his pledge:

If someone steals and sells [something] and the original owners did not despair [of recovering it], and afterward the thief was identified and witnesses testified that the object that So-and-So [the thief] sold is what he stole in front of us, the object returns to its original owners, and the owners give to the buyer the money that he paid the thief due to the enactment of the market (takkanat ha-shuk), and the owners then have to claim in court against the thief [the money that they had to pay to the buyer]. If, however, he was a known thief, the Rabbis did not apply the enactment of the market, and the owners give nothing to the buyer but rather the buyer must claim in court against the thief [the money he paid the thief] and extract from him the money that he [the thief] took for it. ${ }^{35}$

In our case, however, Mr. Jones was not a known thief, and the enactment of the market applies. That is, as explained earlier, to engender security in the market, the Rabbis ruled that a buyer who did not know that the seller was a thief can get his money back from the original owners when he returns the object, and the owners have to take the thief to court for the money they had to pay the buyer. That is, Jewish law provides that even without a change in form, if a thief or robber sold or gave the stolen object or money to a third party who did not have reason to suspect that it was stolen, the exchange of the property (shinnuy reshut) - that is, the change of possession - together with the owners' despair of getting it back is sufficient to confer ownership on the buyer or recipient. Maimonides states the law with regard to burglary as follows, and Joseph Caro quotes him almost verbatim:

If the owner abandons hope of recovering the stolen article, whether he first abandons hope and then the thief sells it, or he abandons hope after the thief has sold it, the purchaser acquires title to it as a result of the change in possession and the owner's abandonment of hope of recovery, and the purchaser need not return the stolen property itself to the owner. If the purchaser bought it from a notorious thief, he must give the owner its value; but if the seller was not a notorious thief, the purchaser gives the owner nothing. ${ }^{36}$

As the Shulhan Arukh makes clear, the same rule applies to robbery:

If the robber had sold it or given it away as a gift, even though the robbed object had not changed, it itself does not return from the hand of the buyer because the owners have despaired [of getting it back], whether before the sale or gift or after the sale or gift; the buyer has acquired it through [the owners'] despair and the change of possession. ${ }^{37}$

\footnotetext{
${ }^{35}$ M.T. Laws of Burglary 5:2.

${ }^{36}$ M.T. Laws of Burglary (Genaivah) 2:3; S.A. Hoshen Mishpat 356:3. Maimonides is getting his distinction about acquiring from a notorious thief as opposed to anyone else from the Talmud's discussion of Hanan the Scoundrel; see B. Bava Kamma 115a.

${ }^{37}$ S. A. Hoshen Mispat 362:3.
} 
With regard to both burglary and robbery, the Tur (Rabbi Jacob ben Asher, 12701340, Germany and then Spain), in the name of his father, the Rosh (Rabbenu Asher ben Yehiel, c. 1250-1327, Germany and then Spain) and the Rema (R. Moses Isserles, c.1525-1572, Poland) disagree with Maimonides and Rabbi Caro in that the Rosh and the Rema require that the owners' despair of retrieving their object come before the change in possession to make it legally effective to transfer ownership ${ }^{38}$; but both Maimonides and Caro, as quoted above, take the more lenient position, maintaining that even if the owners despair of retrieving their property only after the change of possession, that is enough to transfer possession. ${ }^{39}$

One contemporary case in which the purchaser would not acquire ownership under either of these interpretations of Jewish law is that of artwork stolen by the Nazis and then acquired from them, sometimes in a series of purchases after World War II. As we are seeing increasingly, international law agrees with Jewish law on this: because the original owners - or their descendants - may not have even known about their ancestors' possessions and certainly did not despair of recovering them, purchasers must return the artwork to the original owners or their heirs.

Ramah did not buy anything from Mr. Jones; it received money from him as a gift. Nevertheless, as the Shulhah Arukh specifies, the same law applies, for both selling and gifting confer ownership on the receiver, assuming that the original owners despaired of getting their money or object back. ${ }^{40}$ In Genesis 23, Abraham is careful to purchase the cave of Makhpelah to bury Sarah rather than acquire it as a gift, presumably because he thinks that purchasing confers a stronger hold on an acquisition than receiving it as a gift does, and I am told that American law makes the same distinction. As the paragraphs quoted here indicate, however, in

\footnotetext{
${ }^{38}$ Tur, Hoshen Mispat 353:9; S.A. Hoshen Mishpat 356:3, gloss.

${ }^{39}$ This is a debate that begins in the Talmud: B. Bava Kamma 115a. Notice that although generally change of possession coupled with the owner's despair effects a transfer of ownership, there are some exceptions. The Rabbis treated property encumbered to a daughter for her dowry or to a wife for her ketubbah as special cases, such that changing possession (shinnuy reshut) does not effect a change of ownership, even with despair. Specifically, (1) "Dowry may be seized from encumbered properties"; that is, the right of a daughter to a dowry creates a lien on the real property of her father's estate, and so even if his heirs had sold the property, the orphan daughter may collect her dowry from it (B. Ketubbot 69a; B. Gittin 50b; M.T. Laws of Marriage 20:7; Laws of Lending 18:1; S.A. Even Ha-Ezer 113:5). (2) If a husband designated a specific piece of property as the collateral for his wife's ketubbah but subsequently sold it, she can recover that piece of property with an oath and need not accept either cash or equivalent property in exchange (M. Ketubbot 9:8 [middle of the Mishnah, 87a]; see also B. Ketubbot 51a [bottom] and Rashi, s.v. abra'in le'ketubbateikh hayyav); M.T. Laws of Marriage 16:20; M.T. Laws of Lending 22:10; S.A. Even Ha-Ezer 96:9 and S.A. Hoshen Mishpat 98:9, 114:4. (3) If a husband sold any of his wife's real estate during their marriage, the sale is void because he at most has rights of usufruct but not of ownership (B. Bava Batra 50a; M.T. Laws of Marriage 22:15; S.A. Even Ha-Ezer 90:13, 16).

${ }^{40}$ S. A. Hoshen Mishpat 353:3-4.
} 
Jewish law takkanat ha-shuk applies to donations as well as to purchases, and Ramah need not return the donation, whether Ramah acquired it through purchase or as a gift.

The question here, then, is whether the owners despaired of getting their money back. In the specific case, it was the government that Mr. Jones defrauded, and the government clearly did not despair in recovering its money because it prosecuted Mr. Jones with the intention of both punishing him and also recovering what it could. In the plea bargain that Mr. Jones reached with the government, however, the government settled both its criminal and civil suits against him. Thus the government has either recovered the money he stole or agreed to forego it as part of the plea agreement. In the former case, the money Mr. Jones donated was not stolen but rather came from other assets of his; in the latter case, the government has despaired of recovering its money. Thus Ramah has acquired the money Mr. Jones donated either as a legitimate gift from legitimately earned funds or through despair (ya'ush) and transfer of property (shinnuy reshut).

If the government were the only aggrieved party, Ramah would not need to return any money it received from Mr. Jones once the government settled its civil case with him. In cases such as this, though, prosecution by the Securities and Exchange Commission is often followed by civil suits filed by individual stockholders or other aggrieved parties, such as employees and those with whom the accused party contracted for goods or services. Thus Ramah would have full possession of the donated money not yet spent through the combination of transfer of possession and despair of the owners only when both the government's case has been settled and the maximum time under the statute of limitations has run out for individual stockholders or other aggrieved parties to file civil suits against Mr. Jones. That is, despair ( $y a^{\prime} u s h$ ) can be assumed only when both the government's case has been settled and when individuals no longer can file civil suits against $\mathrm{Mr}$. Jones. This would have the practical effect of preventing Ramah from benefiting from any of the unused funds that Mr. Jones donated until a substantial period of time had passed. ${ }^{41}$

In other cases, the non-profit institution would have to examine the following: (a) if the donor was a known thief, the institution should not have taken a donation from him or her in the first place and, if it did, it must now return that money to its rightful owners; (b) if the donor was not a known thief at the time of the donation and the donation did not change form permanently so as to

${ }^{41}$ I would like to thank Dr. Neil Spingarn, of Rabbi Elie Spitz's congregation, for pointing this out to me. 
qualify as a permanent change (shinnuy ma'aseh), the institution must determine whether the original owners despaired, or could legitimately be assumed to have despaired, of retrieving their money or object, whether before or after it was transferred to the possession of the non-profit institution. If they did despair (that is, if there was ya'ush as well as transfer of possession to the nonprofit institution), then the institution may keep it; if not, the institution must return it. The difficulty of meeting this requirement - that is, of demonstrating that the original owner despaired of recouping his or her losses - may give charities incentive to spend donated money rather than keep it in the bank, where it is essentially held conditionally, subject to disgorgement if found to be tainted. ${ }^{42}$

\section{After Conviction: Accepting Further Donations from Mr. Jones or the Jones Family}

Again assuming that Mr. Jones is ultimately convicted of the crimes for which he now stands indicted, what if the Jones family offers to donate more money to Ramah? What if Mr. Jones himself, after paying the compensation and fines and/or serving the prison sentence the court imposes now wants to donate further money to Ramah? May Ramah accept such donations?

As noted above, according to Jewish law, once a person is known to be a thief, people may not buy from him or her or accept any further gifts from him or her. ${ }^{43}$ The Rabbis instituted this prohibition lest buyers from the thief or recipients of gifts from him or her thereby induce the thief to steal more; they then would be violating Leviticus 19:14, "Do not put a stumbling block before a blind man," which the Rabbis understood to mean not only physically blind, but morally blind as well. ${ }^{44}$ So assuming that Mr. Jones is convicted, any future gifts by him must be declined. ${ }^{45}$

There is one exception to this rule, however. If Mr. Jones specifically and publicly indicates that in addition to the compensation, fines, and/or the prison sentence the court imposed, he wants to donate more money to Ramah as a form of teshuvah, of return to proper conduct and the good graces of God and the Jewish community, Ramah may accept such a donation if it has good reason to

\footnotetext{
${ }^{42}$ I would like to thank Professor Robert Katz of the Indiana University School of Law, Indianapolis, for pointing this last point out to me.

${ }^{43}$ M. T. Laws of Burglary, 5:1, 7-9; S.A. Hoshen Mishpat 356:1.

${ }^{44}$ B. Pesahim 22b; B. Mo'ed Katan 17a; B. Kiddushin 32b; B. Nedarim 62b; B. Bava Metzia 5b, 75b. See also

B. Avodah Zarah 6b and 22a, where it is applied to the theologically blind - i.e., those who worship idols.

${ }^{45}$ On this topic generally, see my article, "Nonprofits and Morals: Jewish Perspectives and Methods for Resolving Some Commonly Occurring Moral Issues," in David H. Smith, ed., Good Intentions: Moral Obstacles and Opportunities (Bloomington, IN: Indiana University Press, 2005), pp. 103-126.
} 
believe that Mr. Jones legally earned the money it is now getting and is genuinely engaged in the process of teshuvah. His intentions, of course, are difficult, if not impossible, to determine. As a result, people might presume that Mr. Jones is just trying to buy back respectability, and they might say that Ramah should not be the vehicle to enable him to do that. Still, one must judge one's fellow's intentions favorably, ${ }^{46}$ especially when they are accompanied by good deeds, and so if Ramah can be assured that the new money was legitimately earned, it may accept additional donations from him as part of his teshuvah. Further, as noted above, it may definitely take the money if the victims of Mr. Jones' thievery are not known, for then the way that Jewish law would have him compensate his unknown victims is by contributing to a public charity. ${ }^{47}$ The Jewish tradition believes strongly in the need for, and the power of, return (teshuvah). ${ }^{48}$

Even so, one may not do anything to entice a transgressor to repeat the transgression for fear of putting a stumbling block before the blind in violation of Leviticus 19:14. Thus after serving a prison sentence and fulfilling the other requirements of teshuvah, a pedophile, for example, may not be entrusted with leading a youth group. Even though Jewish law maintains that one can fulfill all the requirements of return only by ultimately acting differently in the same situation, we may not expose children to the risk of such a process, and so pedophiles can take many of the steps of return but cannot complete the process. ${ }^{49}$

\footnotetext{
${ }^{46}$ M. Avot 1:6; see also 6:6.

${ }^{47}$ See note 34 above.

${ }^{48}$ M.T. Laws of Return (teshuvah) Chapters 1 and 2 generally, and 3:14 for the power of teshuvah even to erase the penalty of egregious sins that deprive a person of a place in the World to Come. For a general description of the nature, scope, and power of these laws, see Dorff, Love Your Neighbor and Yourself (at note 23 above), Chapter Six.

The Jewish tradition believes so much in the importance and power of teshuvah that if Mr. Jones had come forward on his own to admit his crimes, rather than being convicted in a court, and if the stolen money or object no longer exists, Jewish law requires that we not accept his offer to pay for what he stole from his own assets for fear of dissuading others from admitting their crimes lest they lose everything they own. Instead "we must help him [to fulfill the requirements of teshuvah] and forgive him so as to make the right path accessible to those who are repentant; and anyone who takes back from him the money of the theft, the spirit of the Sages is not pleased with such a person.” (M.T. Laws of Burglary and Loss 1:13, based on B. Bava Kamma 94b; see also M.T. Laws of the Lender and Borrower 4:5; S.A. Hoshen Mishpat 366:1).

In sum, then, (1) If the stolen property exists, the thief must return it, and we accept it from the thief even if that person engages in a process of teshuvah. (2) If the stolen property exists, but the thief would suffer great loss in returning it (for example, a beam that he built into a building, where there has been a change of form), the thief instead pays the worth of what he or she stole and not the actual object itself because of the Rabbis' enactment for those who repent (takkanat ha-shavim). (3) If the stolen property no longer exists and the thief comes on his own to admit his crime, we do not accept from him his own money or other assets to compensate the victim so as to encourage those who do wrong to engage in teshuvah. (4) If the stolen property no longer exists and the thief did not come on his own to admit his crime but rather was convicted in court, the thief must pay for what he stole from his own assets.

${ }^{49}$ See Elliot N. Dorff, "Family Violence," www.rabbinicalassembly.org, under the link, "Contemporary Halakhah"; printed in Kassel Abelson and David J. Fine, eds., Responsa 1991-2000 of the Committee on Jewish Law and Standards of the Conservative Movement (New York: Rabbinical Assembly, 2002), pp. 773816, esp. pp. 808-811; and in Dorff, Love Your Neighbor and Yourself (at note 24 above), Chapter Five, esp. pp. 196-200.
} 
Here, however, if, for example, the court barred Mr. Jones from earning money in the way he previously did and he now earns a living in a completely different way, and if one can reasonably be assured that the new gift comes from his new, legitimately procured funds, one may accept it as the act of return that he needs and intends. Mr. Jones' status as a convicted and therefore known thief (a ganav mefursam), however, shifts the burden of proof: although ordinarily a charity may assume that donations to it have been legitimately earned, if a convicted thief wants to donate to the charity, it must examine the source of the money to determine that it was legitimately earned.

The situation is more complicated if the Jones family wishes to donate more money to Ramah. That is permissible in either of two ways. (1) If, before conviction, Mr. Jones transferred money to other members of the family who did not know that it was earned illegally, thus making that money the separate property of other family members, then the change in ownership from the thief to innocent and unknowing parties conveys ownership to them if the original owners despaired of recovering it or are unknown, according to the principle discussed above that a change of possession (shinui reshut) together with despair of the owners (ya-ush ba'alim) has that power. The other family members may therefore now use some or all of the money Mr. Jones gave them to make a donation.

(2) The other situation in which Ramah may take Jones family money is if it can be shown that only a minority of the money comes from Mr. Jones and it is not known whether that portion was stolen or not. As Maimonides states the Talmudic law:

It is forbidden to benefit from a robber. But if the minority was his, then even though most of his money is robbed, it is permitted to benefit from him until (and unless) one knows for certain that this thing in his hand is robbed. ${ }^{50}$

\section{Rulings (Peskei Halakhah):}

1. Indictment vs. conviction. Until and unless Mr. Jones is convicted, Jews individually and collectively must think and act toward him on the strong presumption in American law and the even stronger presumption in Jewish law that he is innocent. To do otherwise would violate the ban on slander (motzi shem ra). 2. Names on facilities. Even if Mr. Jones is convicted, either through his own confession or through a finding of the court, unless his family specifically requests that their name be removed from the facility that they donated, Ramah should not

${ }^{50}$ M.T. Laws of Robbery and Loss 5:8; based on B. Bava Kamma 119a. 
remove their name. To do so would actually violate Jewish laws prohibiting public embarrassment of innocent family members.

If the building is named solely for Mr. Jones, whether to remove his name depends in part on community standards. What, besides crimes, would lead the nonprofit to remove the names of donors? The answer to this question affects the amount of shame involved in doing it in this instance.

The acceptability or desirability of removing Mr. Jones' name also depends on the level of his crime. This particular case is a middle ground where judgment is required. If Mr. Jones had violated the law in a much less serious way, then the question of shaming him by removing his name from the facility should not even arise. If, on the other hand, Mr. Jones had committed a violent crime, multiple crimes involving the oppression of individuals and society in general, or much more extensive fraud than Mr. Jones is alleged to have committed in this specific case, then Ramah or any other nonprofit organization should remove his name from the facility so that people do not think that the nonprofit honors the kinds of acts that Mr. Jones committed.

In any case, the community has a duty to give emotional and other forms of support to the innocent members of Mr. Jones' family and even to Mr. Jones himself as they go through this painful period in their lives, for they are, after all, members of our community-indeed active and contributing members-who should be thought of not solely for the crime that Mr. Jones committed but also for the good that he and his family have done.

3. Money already used. Even if Mr. Jones is convicted of the crimes for which he is now indicted, Ramah need not return the money that had already been used to erect the building that bears the family's name because a permanent change of form and despair of the original owners have occurred. In other cases, the nonprofit institution must determine whether both elements have occurred in order to be legally entitled on these grounds to keep the money or objects donated.

4. Money not yet used. Again, even if Mr. Jones is convicted of the crimes for which he is now indicted, Ramah need not return the money the family donated that had not yet been used on the grounds of a transfer of possession together with the owners' despair of retrieving their property once both the government and all aggrieved parties have settled their cases with him or the statute of limitations has run out for any aggrieved parties to file further civil suits. In other cases, the nonprofit institution must determine whether both of these elements have occurred to determine whether the non-profit organization is legally entitled on these 
grounds to keep the money or the objects donated on the grounds of both transfer of possession (shinnui reshut) and despair (ya'ush). If both transfer of possession and the owner's despair have occurred, they make keep it; if not, they must return it. 5. Accepting further donations from Mr. Jones. If Mr. Jones is convicted of what he is accused of doing, Ramah may not accept any more money from him unless (a) Mr. Jones has publicly specified that in addition to the compensation, fines, and/or prison time the court imposed he wants to make this further donation as part of his process of teshuvah and (b) Ramah can determine that he earned the new money legitimately. Generally, a nonprofit may assume that donations to it are legally earned, but if the individual is "a known thief," as Mr. Jones is once he was convicted of fraud, Ramah or any other nonprofit must take these extra precautions in order to receive further donations from him in accordance with Jewish law.

6. Accepting further donations from the Jones family. If the Jones family offers to donate more money to Ramah, the camp may accept it if either (a) the assets were transferred before Mr. Jones' conviction to his family members, who received them with no knowledge that they were the fruit of illegal activities (i.e., there had been a change of ownership, a shinnuy reshut, to innocent parties before the indictment) and the original owners had despaired of retrieving their property ( $y a^{\prime}$ 'ush), along the lines defined in ruling (4) above; or (b) the assets of Mr. Jones himself are a minority of what the Jones family is contributing and it is not known whether his portion was stolen or not.

7. Protecting the reputation of the nonprofit agency. Even though it is legally permissible to act in the ways described in (2), (3), (4), (5), and (6), if Mr. Jones is convicted of the crimes for which he has been indicted, the Ramah Board may decide that it is in the camp's best interests to return the money it received from the Jones family or to refuse to accept any more money from them, just as it may decide to accept or reject any other proposed gift from anyone else. Likely considerations in this judgment - although not the only possible ones - are the level of Mr. Jones' crime; the extent to which keeping the Jones' gifts will undermine the mission, values, or reputation of the nonprofit; and the likelihood that keeping the Jones' gifts will deter future donations from others.

These conclusions apply not only to Camp Ramah, but also to any Jewish communal institution, including synagogues, schools, federations, social service agencies, and national or international organizations, such as the United Synagogue of Conservative Judaism and the Rabbinical Assembly. 


\section{Epilogue}

Now that we have seen at least one interpretation of how Jewish law would respond to the questions posed in this paper, it would be enlightening to compare its responses to those of other ethical systems, if only to show that the way Jewish law treats these issues is not obvious. To do that thoroughly would require a completely new paper, but a few short examples will demonstrate some of the ways in which a Jewish legal treatment of moral issues might differ from other ways of approaching them.

Although thinkers might well differ as to how each of the main ethical theories in Western thought might resolve the questions raised in this essay, utilitarians would seek to determine what is the greatest good for the greatest number of people. In line with this tenet, they might argue that the good of society is best served by having a plethora of nonprofit organizations that help society achieve important social, educational, and cultural goals, and so we should simply say that any money donated to a nonprofit belongs to it, regardless of how it was earned. We might still punish monetary crimes in order to deter fraud in the future, but we should not undermine nonprofits by paying too much attention to the sources of their income.

That is at least one possible reading of how utilitarians might respond to our questions. It would share with Jewish law an interest in protecting buyers or receivers of gifts from having to return property that, unbeknownst to them, did not legitimately belong to the seller or donor, but it would differ from Jewish law in judging all these questions in terms of the communal good.

The opposite would probably be true for the way in which my Jewish legal analysis would relate to a deontological ethic, such as those of Immanuel Kant or W. D. Ross. For them, moral principles and intentions are the most important factors in evaluating the morality of an act, even if terrible consequences result. So a thoroughgoing deontologist might say that nonprofits must thoroughly investigate the sources of all donations, rejecting not only those that were stolen outright but even those that were morally tainted in other ways, such as being the profit of sweatshops.

Jewish law would take a position in between these two extremes, recognizing the pragmatic need to assure buyers and nonprofits that their acquisitions are secure while also worrying that theft not be condoned or rewarded. It is precisely because Judaism uses law and not overarching formulas or principles that it can make fine distinctions among various actions, approving 
some and disapproving others. Because Jewish law is largely a case-based system rather than a code-based one, it can focus on the nuances of the questions involved in the specific situations that raise moral questions. Because Jewish law is a religious legal system, it can call us to a higher moral plane than we might reach if left on our own, teaching us norms that are realistic while enabling us to be more like God. 


\section{Elliot N. Dorff}

\section{Rector and Distinguished Professor of Philosophy Jewish University}

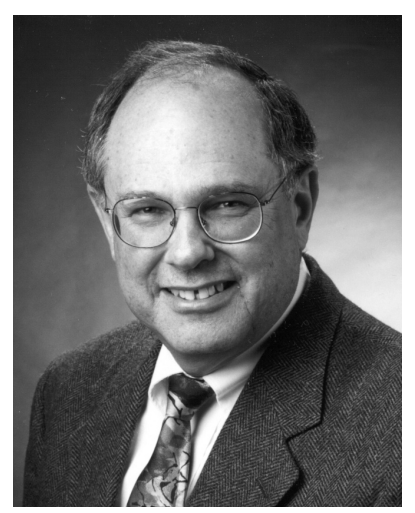

Elliot Dorff, Rector and Distinguished Professor of Philosophy at American Jewish University, earned his Ph.D. in philosophy with a dissertation in moral theory. Since then he has directed the rabbinical and Masters programs at American Jewish University for 23 years. For 30 years, he also taught a course on Jewish law at UCLA School of Law as a Visiting Professor. He was awarded the Journal of Law and Religion's Lifetime Achievement Award, and he holds three honorary doctoral degrees.

Rabbi Dorff is Vice-Chair of the Conservative Movement's Committee on Jewish Law and Standards and served on the editorial committee of Etz Hayim, the new Torah commentary for the Conservative Movement. His papers have formulated the validated stance of the Conservative Movement on infertility treatments and on end-of-life issues, and his Rabbinic Letters on human sexuality and on poverty have become the voice of the Conservative Movement on those topics.

He has chaired three scholarly organizations: the Academy of Jewish Philosophy, the Jewish Law Association, the Society of Jewish Ethics. In Spring, 1993, he served on the Ethics Committee of Hillary Rodham Clinton's Health Care Task Force. In March, 1997 and May, 1999, he testified on behalf of the Jewish tradition on the subjects of human cloning and stem cell research before the President's National Bioethics Advisory Commission. In 1999 and 2000 he was part of the Surgeon General's commission to draft a Call to Action for Responsible Sexual Behavior; and from 2000 to 2002 he served on the National Human Resources Protections Advisory Commission, charged with reviewing and revising the federal guidelines for protecting human subjects in research projects. He is currently working on a project on Judaism and genetics for the American Association for the Advancement of Science, and he is a member of that organization's Dialogue on Science, Ethics, and Religion Advisory Committee. He is also a member of the Ethics Committee charged with establishing the moral norms that govern stem cell research in the State of California. 
In Los Angeles, he is Immediate Past President of Jewish Family Service, and he is a member of the Ethics committees at the Jewish Homes for the Aging and UCLA Medical Center. He serves as Co-Chair of the Priest-Rabbi Dialogue of the Los Angeles Archdiocese and the Board of Rabbis of Southern California, and he is a Vice-President of the Academy for Jewish, Christian, and Muslim Studies.

Rabbi Dorff's publications include over 200 articles on Jewish thought, law, and ethics, together with 13 books:

1. Jewish Law and Modern Ideology (1970).

2. Conservative Judaism: Our Ancestors to Our Descendants (1977; 2nd, revised edition: 1996).

3. A Living Tree: The Roots and Growth of Jewish Law (1988) (with Arthur Rosett).

4. Mitzvah Means Commandment (1989).

5. Knowing God: Jewish Journeys to the Unknowable (1992).

6. Contemporary Jewish Ethics and Morality: A Reader (1995) (edited with Louis E. Newman).

7. Matters of Life and Death: A Jewish Approach to Modern Medical Ethics (1998). Finalist for the 1998 National Jewish Book Award in Jewish Thought.

8. Contemporary Jewish Theology: A Reader (1999) (edited with Louis E. Newman).

9. To Do the Right and the Good: A Jewish Approach to Modern Social Ethics (2002), winner of the National Jewish Book Award in Contemporary Jewish Life for 2003.

10. Love Your Neighbor and Yourself: A Jewish Approach to Modern Personal Ethics (2003).

11. The Unfolding Tradition: Jewish Law After Sinai (2005).

12. The Way Into Tikkun Olam (Fixing the World) (2005).

Finalist for the National Jewish Book Award in Contemporary Jewish Life for 2005.

13. For the Love of God and People: A Philosophy of Jewish Law (2007). Rabbi Dorff is married and has four children and five grandchildren - may they increase! 
The Center on Philanthropy's Lake Institute on Faith \& Giving is dedicated to helping people of faith, regardless of their religious persuasion, think creatively and reflectively on the relationship between their faith and their giving. The Institute engages in research, provides resources that will educate and help people better understand giving as a reflection of their faith, and creates venues for civic conversation on this subject.

The Lake Institute on Faith \& Giving honors the legacy of Thomas and Marjorie Lake. Thomas H. Lake served as president and chairman of the Lilly Endowment Inc. for more than 20 years, accepting that leadership role after 30 years at Eli Lilly \& Company, following his retirement as president of the company. The Lake Institute honors Mr. and Mrs. Lake and their many contributions through leadership in philanthropy.

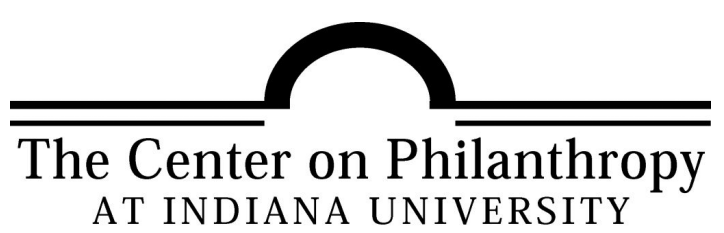

INDIANA UNIVERSITY • PURDUE UNIVERSITY • INDIANAPOLIS 